\title{
Effect of medium -fat diets containing flaxseed, sesame seeds and their oils on non-alcoholic fatty liver disease in rats.
}

\author{
Ashraf Abd El- Aziz, Ayman Fathey Khalil, Eriny Willson Nageb
}

Samar El-Sayed Mohamed

\begin{abstract}
containing flaxseed, sesame seeds and their oils on non-alcoholic fatty liver disease (NAFLD) in rats, from some nutritional and biochemical parameters, in addition to estimate the chemical composition and fatty acids of the two types of the tested seeds. Fifty-four adult male Albino rats (Sprague Dawley strain), were used in this study and divided into two main groups. The first main group (6 rats) fed on basal diet, as a control negative group. The second main group (48 rats) fed on high fat diet (HFD) for 6 weeks to induce non-alcoholic fatty liver disease, after confirmation rats were randomly assigned to eight equal subgroups: Subgroup (1): fed on high fat diet (HFD) and used as a control positive group (+ve)1. Subgroup (2): fed on medium fat diet (MFD) and used as a control positive group (+ve)2. Subgroup (3): fed on (MFD), replace (10\% sheep tallow with $10 \%$ flax seeds oil). Subgroup (4): fed on (MFD), replace (10\% sheep tallow with flax seeds which provided the diet with $10 \%$ oil). Subgroup (5): fed on (MFD), replace (10\% sheep tallow with $10 \%$ sesame oil). Subgroup (6): fed on (MFD), replace (10\% sheep tallow with sesame seeds which provided the diet with 10\% oil). Subgroup (7): fed on (MFD), replace (10\% sheep tallow with 5\% flaxseeds oil and 5\% sesame oil). Subgroup (8): fed on (MFD), replace (10\% sheep tallow with sesame seeds which provided the diet with $5 \%$ oil and flax seeds which provided the diet with $5 \%$ oil). The experiment lasted for 4 weeks. The results indicated that, treating NAFLD rats with MFD containing (10\% flaxseeds oil, flaxseeds which provided the diet with $10 \%$ oil, $10 \%$ sesame oil, sesame seeds which provided the diet with $10 \%$ oil, $10 \%$ (flaxseeds oil and sesame oil) and (sesame and flaxseeds which
\end{abstract}


Samar El-Sayed Mohamed

provided the diet with $10 \%$ oil) led to significant decrease in body weight gain $\%$, organs weight $\%$, peritoneal fat pad PFP /body weight $\%$ PFP, leptin, glucose, lipid profile including (cholesterol, triglycerides, LDL-c and VLDL-c), liver enzymes including (AST, ALT and ALP), while these treatments induced significant increase in feed intake, HDL-c and antioxidant enzymes including (GSH-GPx, SOD and CAT). The medium fat diet MFD alone or MFD containing the tested seeds and their oils improved the nutritional and biochemical parameters in non-alcoholic fatty liver disease, especially the group fed on MFD containing the combination of flaxseeds and sesame seeds which provided the diet with $10 \%$ oils, followed by the group fed on MFD containing $10 \%$ combination of these oils. The medium fat diet MFD which contain the combination of flaxseeds and sesame seeds, or their oils improved the health status of rats suffering from non-alcoholic fatty liver disease

Key words: Flaxseeds, Sesame seeds, Non-alcoholic fatty liver, High fat diet, Lipid profile, Liver enzymes, Antioxidant enzymes and rats

\section{Introduction}

Fat accumulation in the liver (hepatic steatosis) from non-alcoholic called Non-alcoholic fatty liver disease (NAFLD), this disease affects about 1.80 billion people (Younossi et al., 2016). In this respect, in 2009 Bellentani and Marino reported that, $10-35 \%$ of the adult population in the worldwide suffering from NAFLD. On the other hand, Alberti et al., (2005) decided that hypertension, insulin resistance, obesity and dyslipidemia occur during NAFLD. Aside from the gain of weight and also obesity, the dietary composition, types and the amount of fat induced the development of NAFLD, in this respect, Donnelly et al., (2005) reported that, feeding three day isoenergetic diet 
containing $30 \%$ energy from fat increased the level of triglyceride by about $15 \%$ in the liver which derived from dietary fat.

High-fat diets (HFD) increased body weight, body fat and liver fat levels which associated with insulin resistance in rodent models (Samuel et al., 2004). On the other hand, Anstee and Goldin (2006) reported that, feeding mouse models on HFD does not produce liver fibrosis and only mild steatosis. While Kien, (2009) and Tanaka et al., (2008) reported that, high intake of dietary fat which contain an increase of the ratio of $\omega-6 / \omega-3$ and increase the intake of saturated fatty acids associated with liver inflammation and NAFLD. On the other side, Araya et al., (2004) reported also, Omega-3 polyunsaturated fatty acids PUFA levels decreased in the hepatic tissue of patients with NAFLD, while the ratio increased of $\omega-6 / \omega-3$ may contribute to the development of a fatty liver because of a decreased capacity to regulate liver lipid metabolism. Cortez-Pinto et al., (2006) reported that, lower dietary intake of $\omega-3$ fatty acid led to NAFLD in individuals than that of healthy control. While Kabisch et al., (2018) found that, low-fat diets led to liver fat reduction.

Flaxseed (Linum usitatissimum) consists of $41 \%$ fat, $20 \%$ protein, and 28\% fiber (by weight) (Singh et al., 2011 and Katare et al., 2012). Flaxseed contain high amount of $\omega$-3 PUFA, which are reported in the above to have significant hepatoprotective properties and preventing oxidative stress as well as liver inflammation (Parker et al., 2012 and Hussein et al., (2016). One cup of whole flaxseed 
Samar El-Sayed Mohamed

has approximately 23\% $\alpha$-linolenic acid (ALA) (by weight). Flaxseed contain several phenolic compounds including (35 to $70 \mathrm{mg} / 100 \mathrm{~g}$ flavonoids) and (1 to 26 $\mathrm{mg} / 100 \mathrm{~g}$ lignans) (Martinchik et al., 2012 and Silva et al., 2013). Regarding flaxseed oil Ganorkar and Jain (2013) reported that, this oil contains a combination of fatty acid which is characterized by its high content of polyunsaturated fatty acid, especially (ALA) which constitutes $57 \%$ of the total fatty acids in flax.

Sesamum indicum (Pedaliaceae) is the traditional health food around the world, sesame meal is the residue after pressing the oil from the seed, and it is an excellent source of protein $47.1 \%$ to $52.9 \%$ (Kaneko et al., 2002). Sesame oil contains mono and polyunsaturated fatty acids, these fatty acids are good for heart healthy, because it lowers blood pressure and also cholesterol. In addition, sesame oil contains vitamin E and other antioxidant compounds known as lignans (Sankar et al., 2006). Therefore, the present study designed to evaluate the effect of medium -fat diets containing flaxseed, sesame seeds and their oils on non-alcoholic fatty liver disease in rats.

\section{Material and Methods}

\section{Materials:}

1-Casein, vitamins, minerals, cellulose and choline chloride obtained from El-Gomhorya Company, Cairo, Egypt.

2-Soy, sesame seeds (Sesamum indicum L.) and flaxseeds (Linum usitatissimum) obtained from Agricultural research center, Giza, Egypt. 
3- Starch obtained from local market, Cairo, Egypt.

4- Kits for biochemical analysis obtained from Alkan for pharmaceutical and chemical, Dokki, Egypt.

\section{Animals:}

Male albino rat Sprague Dawley strain weighting 200 $\pm 10 \mathrm{~g}$ purchased from Helwan farm for experimental animals, Ministry of Health and Population, Helwan, Cairo, Egypt.

\section{Methods:}

\section{Chemical analysis:}

Moisture, total protein, total lipid, carbohydrate and fiber were analyzed and calculated in sesame and flax seeds chemically according to (A.O.A.C. 2000), while extraction of oils and fatty acids composition were determined in sesame oil and flaxseeds oil, according to (Gunstone et al., 1994 and Yeshajahu, 1994).

\section{Experimental Animals:}

Animals: Fifty-four (54) adult male Albino rats of (Sprague Dawley strain), weighting $200 \pm 10 \mathrm{~g}$ were used in this study. All rats were fed the control (basal diet) diet for 4 consecutive days for adaptation. Each rat was housed in an individual stainless steel cage under hygienic controlled condition. Diets were introduced to rats in a special non scattering feeding cup to avoid loss of food and contamination. Tap water was provided to rats by means of glass tubes projecting through wire cages from inverted bottles supported to one side of the cage. 
Basal Diet: the basal diet consists of casein (14\%), corn oil $(4 \%)$, choline chloride $(0.25 \%)$, and vitamin mixture $(1 \%)$, cellulose $(5 \%)$ and the remainder is corn starch according to Reeves et al, (1993), salt mixture which used in these study according to Hegsted et al., (1941) and vitamin mixture prepared according to A.O.A.C. (1975).

After adaptation period, the rats divided into two main groups as follows: The first main group: (6 rats) fed on basal diet, as a control negative group. The second main group (48 rats) fed on high fat diet used to induce nonalcoholic fatty liver disease according to Zarghani et al., (2016) ; containing (carbohydrate 55.6\% ; "starch 21.6\%, sucrose $30 \%$ and fructose 4\%"), (Fat 27.5\% ; "soybean oil $2.5 \%$, hydrogenated oil $5 \%$ and sheep tallow $20 \%$ '), protein $8.2 \%$, cellulose $4.2 \%$, salt mixture $3.5 \%$ and vitamin mixture $1 \%$. After 6 weeks' body weight gain \%, serum lipid, cholesterol and triglycerides were determined in the first and second main groups, to insure the induction of obesity and fatty liver, then the second main group divided into eight subgroups as the following:

Subgroup (1): fed on high fat diet (HFD) all over the experimental period, as a control positive group ( $+\mathrm{ve})$. Subgroup (2): fed on medium fat diet (MFD) containing (Fat 13.75\% "soybean oil 1.25\%, hydrogenated oil $2.5 \%$ and sheep tallow $10 \%$ '), protein $8.2 \%$, cellulose $4.2 \%$, salt mixture $3.5 \%$ and vitamin mixture $1 \%$ and the remainder was corn starch as position Cont.2. Subgroup (3): fed on (MFD), replace (10\%sheep tallow with $10 \%$ flax seeds oil). Subgroup (4): $\quad$ fed on (MFD), replace (10\%sheep tallow with flax seeds which provided the diet 
with 10\% oil). Subgroup (5): fed on (MFD), replace (10\%sheep tallow with 10\% sesame oil). Subgroup (6): fed on (MFD), replace (10\%sheep tallow with sesame seeds which provided the diet with 10\% oil). Subgroup (7): fed on (MFD), replace (10\%sheep tallow with $5 \%$ flaxseeds oil and 5\% sesame oil). Subgroup (8): fed on (MFD), replace (10\%sheep tallow with sesame seeds which provided the diet with $5 \%$ oil and flax seeds which provided the diet with $5 \%$ oil).

During the experimental period (28 days), the diets consumed and body weights were recorded twice weekly according to Chapman et al., (1959). At the end of the experiment, the animals were fasted overnight, and then the rats were anaesthetized and sacrificed. Blood samples were collected from the aorta. Blood samples were centrifuged and the serum was separated to estimate some biochemical parameters, i.e. serum leptin hormone according to Guillaume and Bjorntorp (1996), glucose (Trinder, 1959), cholesterol (Allain et al., 1974), triglycerides (Foster and Dumns, 1973), high density lipoprotein HDL-c (Lopes-Virella et al., 1977), low density lipoprotein LDL-c and VLDL-c calculated according to (FriedWald et al., 1972), Aspartate Amino Transferase (AST) and Alanine Amino Transferase (ALT) by Reitman and Frankel, (1957), alkaline phosphatase (ALP) by Belfield and Goldberg, (1971). In the liver tissue homogenate catalase (CAT), superoxide dismutase (SOD) and reduced glutathione (GSH) activities were measured according to the methods described by Aebi, (1984) ; Beauchamp and Fridovich (1971) and Ellman (1959) respectively. 
Samar El-Sayed Mohamed

Liver, kidney and peritoneal fat pad were separated from each rat and weighted to calculate the liver, kidney and peritoneal fat pad / body weight $\%$. After that, a specomen from each liver was stored in refrigerator until homogenate preparation. Results of biological evaluation of each group were statistically analyzed (mean \pm standard deviation and one-way ANOVA test) by using SPSS package Ver.25 and compared with each other using the suitable test (least significant differences at $\mathrm{P}<0.05$ ) according to (Sendecor and Cochran, 1979).

\section{Results and Discussion:}

\section{Chemical composition of sesame and flaxseed.}

Chemical analysis of flaxseeds and sesame seeds presented in Table (1). The data presented in this table showed that, the mean value of moisture and fiber were higher in flaxseeds than that of sesame seeds, while the amount of protein, oil, ash and carbohydrates were higher in sesame seeds than that of flaxseeds. Our results agree with Morris, (2003), who found that, the averaged of fat, protein, dietary fiber, moisture and ash in brown Canadian flax $41 \%, 20 \%, 28 \%, 7.7 \%$ and $3.4 \%$ ), respectively. On the other hand, Daun and DeClercq, (1994), reported that, the protein content of the flaxseeds decreases as the oil content increases.

Nzikou et al., (2009) analyzed the chemical composition of sesame seeds and found that, the seed contained $5.7 \%$ moisture, $20 \%$ crude protein, $3.7 \%$ ash, $3.2 \%$ crude fiber, $54 \%$ fat and $13.4 \%$ carbohydrate. Other study by Borchani., et al., (2010) showed that, the chemical 
composition of sesame seed is an important source of oil (44 - 58\%), protein $(18-25 \%)$, carbohydrate $(\sim 13.5 \%)$ and ash $(\sim 5 \%)$.

Table (1): Chemical composition of sesame seeds and flaxseed (g/100g Dry weight).

\begin{tabular}{|c|c|c|}
\hline $\begin{array}{ll}\text { Nutrients } & \text { Samples } \\
\end{array}$ & Flaxseed & Sesame seeds \\
\hline Moisture* & 6.75 & 5.1 \\
\hline Protein* & 18.34 & 19.4 \\
\hline Oil* & 42.00 & 51.33 \\
\hline Ash* & 3.54 & 4.0 \\
\hline Fiber* & 27.00 & 4.2 \\
\hline Carbohydrate & 2.37 & 15.97 \\
\hline
\end{tabular}

* The average of two estimates

\section{Fatty acids composition of sesame seeds and flaxseed oils (g/100g)}

The fatty acid composition of flaxseeds and sesame seeds oils presented in Table (2). Saturated fatty acid (SFA) of flaxseeds oil was $14.85 \%$. Palmitic acid (C16:0) was the major SFA presented in this oil $(8.35 \%)$, followed by stearic acid C18:0 (5.44\%). On the other hand, SFA of sesame seeds oil was $(37.72 \%)$, most of them short and medium chain fatty acids included (caprylic acid C8:0, capric acid C10:0 and lauric acid C12:0). The other major SFAs in sesame seeds oil were, palmitic $(8 \%)$, stearic $(5.11 \%)$ and myristic (4\%) respectively.

Oleic acid (C18:1) were higher in sesame seeds oil, as compared to flaxseeds oil $(30.77 \%$ vs. $22.25 \%)$, respectively. The total amounts of polyunsaturated fatty acid PUFA were higher in flaxseeds oil than that of sesame seeds oil (61.95\% vs. 30.60\%). Linoleic acid (C18:2) was the 
major PUFA in sesame seeds oil (30.31\%), while alphalinolenic acid (C18:3) was the major PUFA in flaxseeds oil $(46.08 \%)$.

In this respect, Morris, (2003) reported that, the averaged of saturated fat, monounsaturated fat, linoleic acid (omega-6 fattyacid) and $\alpha$-Linolenic acid (omega-3 fatty acid) in flaxseed oil were (9\%, 18\%, 16\% and 57\%), respectively.

On the other hand, Nzikou et al., (2009) reported that, sesame seeds oil contain high levels of unsaturated fatty acids, especially oleic (up to $38.84 \%$ ) and linoleic (up to $46.26 \%$ ). Sesamum indicum L. oil can be classified in the oleic-linoleic acid group. The dominant saturated acids were palmitic (up to $8.58 \%$ ) and stearic (up to $5.44 \%$ ).

Table (2): Fatty acid composition of sesame oil and flaxseed oil (g/100g).

\begin{tabular}{|l|c|c|}
\hline \multicolumn{1}{|c|}{ Samples } & Flaxseeds & Sesame seeds \\
\hline Fatty acids & -- & 3.00 \\
\hline Caprylic acid (C8:0) & -- & 2.27 \\
\hline Capric acid (C10:0) & -- & 14.50 \\
\hline Lauric acid (C12:0) & -- & 4.00 \\
\hline Myristic acid (C14:0) & 8.35 & 8.00 \\
\hline Palmitic acid (C16:0) & -- & 0.05 \\
\hline Heptadecanoic acid (C17:0) & 5.44 & 5.11 \\
\hline Stearic acid (C18:0) & 0.22 & 0.55 \\
\hline Arachidonic acid (C20:0) & 0.43 & 0.15 \\
\hline Behenic acid (C22:0) & 0.41 & 0.09 \\
\hline Lignoceric acid (C24:0) & 22.25 & 30.77 \\
\hline Oleic acid (C18:1) & 0.08 & 0.05 \\
\hline Palmitoleic acid (C16:1) & 15.75 & 30.31 \\
\hline Linoleic acid (C18:2) & 46.08 & 0.21 \\
\hline Alpha-linolenic acid (C18:3) & 0.12 & 0.08 \\
\hline Eicosanoic acid (C20:2) & 14.85 & 37.72 \\
\hline SFA & 22.33 & 30.82 \\
\hline MUFA & 61.95 & 30.6 \\
\hline PUFA & 0.87 & 0.86 \\
\hline Unknown & &
\end{tabular}


The effect of medium-fat diets containing flaxseeds, sesame seeds and their oils on feed intake and body weight gain $\%$ of non-alcoholic fatty liver disease in rats presented in Table (3). The mean value of feed intake (g/day/each rat) decreased in the control $(+\mathrm{ve})^{1}$ (Non-alcoholic fatty liver disease NAFLD group) which fed on high fat diet HFD, as compared to healthy rats fed on basal diet. On the other hand, fed intake of rats which suffer from non-alcoholic fatty liver disease and fed on medium fat diet (MFD) ${ }^{2}$, increased significantly $\mathrm{p} \leq 0.05$, as compared to control $(+\mathrm{ve})^{1}$.

Feeding non-alcoholic fatty liver disease rats on MFD containing $10 \%$ sesame seeds oil SSO, $10 \%$ flax seeds oil $\mathrm{FSO}, 5 \% \mathrm{SSO}+5 \% \mathrm{FSO}$ and their seeds which provided the diet with $10 \%$ oils led to significant increase $(\mathrm{P} \leq 0.05)$ in the mean values of feed intake, as compared to the positive control groups. The highest increase in the mean value of feed intake recorded for NAFLD group fed on MFD containing SS and FS, which provided the diet with $10 \%$ oils, this treatment showed non-significant changes in feed intake, as compared to the negative control group. 
Samar El-Sayed Mohamed

Table (3): Effect of medium-fat diets containing flaxseeds, sesame seeds and their oils on feed intake and body weight gain\% of nonalcoholic fatty liver disease in rats.

\begin{tabular}{|c|c|c|c|}
\hline \multicolumn{2}{|c|}{$\mathrm{O}_{\text {Groups }}^{\text {Parameters }}$} & $\begin{array}{l}\text { Feed intake } \\
\text { (g/day/each } \\
\text { rat) }\end{array}$ & BWG\% \\
\hline \multicolumn{2}{|c|}{ Control (-ve) } & $\begin{array}{l}19.700^{\mathrm{a}} \\
\pm 0.447\end{array}$ & $\begin{array}{l}19.498^{f} \\
\pm 0.402\end{array}$ \\
\hline \multicolumn{2}{|c|}{ Control $(+v e)^{1}$} & $\begin{array}{l}16.188^{\mathrm{f}} \\
\pm 0.483\end{array}$ & $\begin{array}{l}29.162^{\mathrm{a}} \\
\pm 0.738\end{array}$ \\
\hline \multicolumn{2}{|c|}{$\begin{array}{l}\text { Medium fat diet (MFD) } \\
\text { Control }(+\mathrm{ve})^{2}\end{array}$} & $\begin{array}{l}17.770^{\mathrm{e}} \\
\pm 0.674\end{array}$ & $\begin{array}{l}26.574^{\mathrm{b}} \\
\pm 1.013\end{array}$ \\
\hline \multirow{6}{*}{ 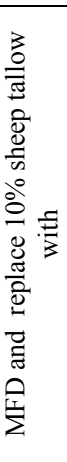 } & $10 \%$ SS oil & $\begin{array}{l}18.138^{\mathrm{de}} \\
\pm 0.352\end{array}$ & $\begin{array}{l}25.846^{b} \\
\pm 0.793\end{array}$ \\
\hline & $\begin{array}{l}\text { SS, which provided the } \\
\text { diet with } 10 \% \text { oil). }\end{array}$ & $\begin{array}{l}18.854^{\mathbf{b c}} \\
\pm 0.511\end{array}$ & $\begin{array}{l}25.973^{b} \\
\pm 0.832\end{array}$ \\
\hline & $10 \%$ FS oil & $\begin{array}{l}18.746^{\mathbf{c d}} \\
\pm 0.578\end{array}$ & $\begin{array}{l}22.538^{\mathrm{c}} \\
\pm 1.019\end{array}$ \\
\hline & $\begin{array}{l}\text { FS, which provided the } \\
\text { diet with } 10 \% \text { oil. }\end{array}$ & $\begin{array}{l}18.500^{\mathbf{c d}} \\
\pm 0.353\end{array}$ & $\begin{array}{l}\underset{\mathrm{de}}{20.294} \\
\pm 0.701\end{array}$ \\
\hline & $5 \% \mathrm{SSO}$ and $\% \mathrm{FSO}$ & $\begin{array}{c}18.934^{\mathrm{bc}} \\
\pm 0.427\end{array}$ & $\begin{array}{l}20.569^{d} \\
\pm 0.859\end{array}$ \\
\hline & $\begin{array}{l}\text { SS and FS, which } \\
\text { provided the diet with } \\
10 \% \text { oils. }\end{array}$ & $\begin{array}{l}19.500^{\mathbf{a b}} \\
\pm 0.500\end{array}$ & $\begin{array}{l}19.477^{\mathrm{e}} \\
\pm 0.404\end{array}$ \\
\hline
\end{tabular}

MFD: Medium-fat diets $\quad$ SS: sesame seeds $\quad$ SSO: sesame seeds oil FS: Flax seeds FSO: Flax seeds oil

Least significant differences at $\mathrm{P} \leq 0.05$.

Means with the same letter are insignificantly difference.

Body weight gain \% (BWG\%) of NAFLD group which was fed on HFD (control +ve) ${ }^{1}$ increased significantly $(\mathrm{p} \leq 0.05)$, as compared to healthy rats fed on basal diet. On the other hand, when fed rats which suffer from NAFLD on MFD (control +ve) ${ }^{2}$, the mean value of BWG $\%$ decreased significantly $(\mathrm{p} \leq 0.05)$, as compared to NAFLD group fed on HFD (control $+v e)^{1}$. Treating NAFLD rats with MFD containing 10\% SSO, 10\% FSO, 5\% $\mathrm{SSO}+5 \% \mathrm{FSO}$ and their seeds which provided the diet with $10 \%$ oils showed significant decrease in $\mathrm{BWG} \%$, as 
compared to the positive control group which fed on HFD, on the other hand, all treated groups showed significant decrease $(p \leq 0.05)$ in $B W G \%$, except NAFLD groups which treated with $10 \% \mathrm{SS}$ oil and sesame seeds which provided the diet with $10 \%$ oil), as compared to the positive control group fed on MFD.

In this respect, some researchers reported that, an excess of body fat tissue may be related not only to energy intake and energy expenditure in humans (Flatt,1995) and (Prentice, 1998), but also to the type of diet, especially high-fat diets (HFD), which may lead to various metabolic alterations such as hyperphagia in humans (Westerterp et al., 2008), reduced lipolytic activity in fat tissue, reduction in leptin secretion and/or sensitivity, hypothalamic neuron apoptosis (Moraes et al., 2009), impairment of mitochondrial metabolism (Pomplun et al., 2007), insulin resistance, and obesity (Wajchenberg, 2000). On the other side, ecological studies between populations tend to show a positive relationship between fat and obesity, especially if populations with low fat intakes (Seidell, 1998). In addition to, extremely low fat, high carbohydrate diets are also very effective for weight loss (Ornish et al., 1990).

Dietary fibers play an important role in body weight regulation, through both hunger suppression and diminished nutrient absorption (Henness and Perry, 2006). Flaxseeds contain $\sim 30 \%$ dietary fibers of which one third are watersoluble and belonging to a group of heterogeneoues polysaccharides (Naran et al., 2008). They can affect multiple aspects of the gastrointestinal function such as 
gastric emptying rate and nutrient absorption rate in the small intestine (Lairon et al., 2007).

Brant et al., (2012) reported that, the development of metabolic syndrome was altered by flaxseed, because it has beneficial effects on lipids and glucose in addition to prevents the excess of body weight gain. Baranowski et al., (2012) reported that, alpha linolic acid (ALA-rich Flaxseed oil induced decrease in adipocyte hypertrophy, protein levels of inflammatory markers in adipose tissue in obese zucker rats. In addition to Kristensen et al., (2011) reported that, flaxseed fibers baked into bread rolls to significantly increase satiety in a dose dependent manner.

Raeisi-Dehkordi et al., (2018) reported that, sesame products consumption did not significantly affect body weight and body mas index BMI $(\mathrm{P}>0.05)$. Only sesame oil significantly decreased the body weight and BMI $(\mathrm{P}<$ $0.05)$. The body fat percent was significantly reduced after sesame consumption $(\mathrm{P}<0.05)$. Sesame consumption did not affect other body composition indices $(\mathrm{P}>0.05)$.

The effect of medium-fat diets containing flaxseeds, sesame seeds and their oils on some organs weight/body weight $\%$ and peritoneal fat pad/body weight $\%$ of nonalcoholic fatty liver disease in rats presented in Table (4).

The data presented in this table revealed that, the mean values of liver, kidney and peritoneal fat pad PFP/body weight \% increased significantly in the control $(+\mathrm{ve})^{1}$ group (NAFLD group fed on HFD), as compared to the negative control group fed on basal diet. MFD induced significant decrease $\mathrm{p} \leq 0.05$ in liver, kidney and peritoneal 
fat $\mathrm{pad} /$ body weight $\%$, as compared to the control $(+\mathrm{ve})^{1}$ group. All treated groups with $10 \%$ (SSO, FSO, combination of them) and the seeds which provided the diet with $10 \%$ oils showed significant decrease in the mean value of liver, kidney and peritoneal fat pad/body weight $\%$, as compared to the positive control groups. The highest improvement in decreasing these organs and PFP recorded for the group treated with the combination of (SS and FS), which provided the diet with $10 \%$ oils, followed by the group treated with FS, which provided the diet with $10 \%$ oil.

Schumann et al., (2003) showed that the long-term use of $100 \mathrm{gm} / \mathrm{kg}$ dietary ground flaxseed in laying hen diets reduced liver fat content and liver weight. The addition of the fatty liver supplement in the flaxseed diets also lowered liver malondialdhyde (MDA) content in hens.

Table (4): Effect of medium-fat diets containing flaxseeds, sesame seeds and their oils on organs and PFP of non-alcoholic fatty liver disease in rats.

\begin{tabular}{|c|c|c|c|c|}
\hline \multirow{2}{*}{\multicolumn{2}{|c|}{$\begin{array}{ll}\text { Groups } & \text { Parameters } \\
\end{array}$}} & \multicolumn{2}{|c|}{ Organs weight \% } & \multirow{2}{*}{ PFP\% } \\
\hline & & Liver & Kidney & \\
\hline \multicolumn{2}{|c|}{ Control (-ve) } & $\begin{array}{l}2.733^{\mathrm{e}} \\
\pm 0.048\end{array}$ & $\begin{array}{l}0.486^{\mathrm{g}} \\
\pm 0.024\end{array}$ & $\begin{array}{l}0.923^{\mathrm{g}} \\
\pm 0.099\end{array}$ \\
\hline \multicolumn{2}{|c|}{ Control $(+v e)^{1}$} & $\begin{array}{l}3.365^{\mathrm{a}} \\
\pm 0.048\end{array}$ & $\begin{array}{l}0.768^{\mathrm{a}} \\
\pm 0.014\end{array}$ & $\begin{array}{l}2.124^{\mathrm{a}} \\
\pm 0.066\end{array}$ \\
\hline \multicolumn{2}{|c|}{$\begin{array}{l}\text { Medium fat diet (MFD) } \\
\text { Control }(+\mathrm{ve})^{2}\end{array}$} & $\begin{array}{l}3.241^{\mathbf{b}} \\
\pm 0.035\end{array}$ & $\begin{array}{l}0.690^{\mathbf{b}} \\
\pm 0.033\end{array}$ & $\begin{array}{l}1.933^{b} \\
\pm 0.065\end{array}$ \\
\hline \multirow{5}{*}{ 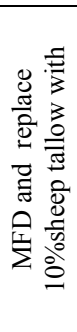 } & $10 \%$ SS oil & $\begin{array}{l}3.068^{\mathbf{c}} \\
\pm 0.056\end{array}$ & $\begin{array}{l}0.640^{\mathbf{c}} \\
\pm 0.025\end{array}$ & $\begin{array}{l}1.704^{\mathrm{c}} \\
\pm 0.066\end{array}$ \\
\hline & $\begin{array}{l}\text { SS, which provided the } \\
\text { diet with } 10 \% \text { oil). }\end{array}$ & $\begin{array}{l}3.013^{\mathbf{c d}} \\
\pm 0.037\end{array}$ & $\begin{array}{l}0.597^{\mathrm{d}} \\
\pm 0.013\end{array}$ & $\begin{array}{l}1.506^{\text {ef }} \\
\pm 0.073\end{array}$ \\
\hline & $10 \%$ FS oil & $\begin{array}{l}3.061^{\mathbf{c}} \\
\pm 0.092\end{array}$ & $\begin{array}{l}0.600^{d} \\
\pm 0.020\end{array}$ & $\begin{array}{l}1.622^{\mathbf{c d}} \\
\pm 0.052\end{array}$ \\
\hline & $\begin{array}{l}\text { FS, which provided the } \\
\text { diet with } 10 \% \text { oil. }\end{array}$ & $\begin{array}{l}2.986^{\mathrm{d}} \\
\pm 0.036\end{array}$ & $\begin{array}{l}0.559^{\text {ef }} \\
\pm 0.031\end{array}$ & $\begin{array}{l}1.482^{\text {ef }} \\
\pm 0.065\end{array}$ \\
\hline & $5 \% \mathrm{SSO}$ and $\% \mathrm{FSO}$ & $\begin{array}{l}2.946^{\mathrm{d}} \\
\pm 0.016\end{array}$ & $\begin{array}{l}0.569^{\mathrm{de}} \\
\pm 0.022\end{array}$ & $\begin{array}{l}1.541^{\mathrm{de}} \\
\pm 0.051\end{array}$ \\
\hline
\end{tabular}

Egyptian Journal for Specialized Studies - Vol (8) N (27) July 2020 
Samar El-Sayed Mohamed

\begin{tabular}{|l|l|c|c|c|}
\hline & $\begin{array}{l}\text { SS and FS, which } \\
\text { provided the diet with } \\
10 \% \text { oils. }\end{array}$ & $\begin{array}{r}2.950^{\mathbf{d}} \\
\pm 0.030\end{array}$ & $\begin{array}{r}0.530^{\mathrm{f}} \\
\pm 0.033\end{array}$ & $\begin{array}{r}1.425^{\mathrm{f}} \\
\pm 0.059\end{array}$ \\
\hline
\end{tabular}

MFD: Medium-fat diets SS: sesame seeds SSO: sesame seeds oil FS: Flax seeds $\quad$ FSO: Flax seeds oil PFP: peritoneal fat pad Least significant differences at $\mathrm{P} \leq 0.05$.

Means with the same letter are insignificantly difference.

The effect of medium-fat diets containing flaxseeds, sesame seeds and their oils on serum leptin and glucose of non-alcoholic fatty liver disease in rats presented in Table (5).

Leptin and serum glucose increased in NALD group which fed on HFD, as compared with healthy rats fed on basal diet. Leptin and serum glucose increased by about $(247.818 \%$ and $74.560 \%)$ in the NALD group (control +ve $)^{1}$ fed on HFD, than that of the negative control group. The increase of leptin and serum glucose decreased in NALD group which fed on MFD, as compared to the group fed on HFD.

Replacement $10 \%$ sheep tallow with $10 \%$ SSO or $10 \% \mathrm{FSO}$ and their combination in the diet which used in feeding NAFLD rats showed significant decrease $p \leq 0.05$ in leptin hormone and serum glucose, as compared to the positive control groups ${ }^{1 \& 2}$, the same trend was observed when used SS, FS and their combination which provided the diet with $10 \%$ oil. The best results in leptin hormone and serum glucose recorded for NAFLD group which treated with MFD containing with the combination of SS and FS, which provided the diet with $10 \%$ oils, followed by the group treated with $\mathrm{FS}$, which provided the diet with $10 \%$ oil, and the combination of $5 \% \mathrm{SSO}$ and $5 \% \mathrm{FSO}$ or the 
group treated with SS, which provided the diet with $10 \%$ oil, respectively.

Our results are in agreement with Fernandez-Riejos et al., (2010) who reported that increased fat mass and larger adipocytes lead to elevated circulating leptin concentration. On the other hand, Bluher and Mantozoros, (2004) also reported that, human obesity is associated with increased level of leptin.

In this respect Kratz et al., (2002) demonstrated that omega 3 fatty acids are considered to be anti-inflammatory and thus may counteract some of the damaging effects of the obese condition. Higher intakes of dietary omega 3 fatty acids are associated with reduced lymphocyte proliferation and Th1 cell development, lower circulating levels of leptin. The dietary ALA-rich flaxseed oil decreased adipocyte size in epididy mal and perirenad adipose tissue Baranowski et al., 2012).

Wang et al., (2013) reported that $\alpha$-linolenic acid increases peripheral insulin sensitivity in obese patients and it may aid the prevention and treatment of type 2 diabetes mellitus and atherosclerotic vascular diseases. Tharwat et al., (2017) reported that, supplemented bakery with flaxseed or flaxseed oil for 12 weeks' decreased body mas index BMI, blood glucose and improved lipid profile in type 2 diabetics, thus incorporating flaxseed in bakery is recommended.

Ramesh et al., (2005) reported that, diabetic rats fed on a diet supplemented with sesame oil $(6 \%)$ decreased the levels of blood glucose compared to the diabetic control. 
Samar El-Sayed Mohamed

Sesame oil contain high amount of monounsaturated fatty acid, the previous studies have suggested that a high monounsaturated fat diet improves glycemic control by exerting protective effect against $\beta$-cell death and augmenting insulin sensitivity (Brehm et al., 2009). On the other hand, Raeisi-Dehkordi et al., (2018) reported that, sesame products consumption did not significantly affect body weight and body mas index BMI $(\mathrm{P}>0.05)$. Only sesame oil significantly decreased the body weight and BMI $(\mathrm{P}<0.05)$. The body fat percent was significantly reduced after sesame consumption ( $\mathrm{P}<0.05)$.

Table (5): Effect of medium-fat diets containing flaxseeds, sesame seeds and their oils on serum leptin and glucose of non-alcoholic

fatty liver disease in rats.

\begin{tabular}{|c|c|c|c|}
\hline \multicolumn{2}{|c|}{$\begin{array}{ll}\text { Groups } & \text { Parameters } \\
\end{array}$} & leptin & Glucose \\
\hline \multicolumn{2}{|c|}{ Control (-ve) } & $\begin{array}{r}3.438^{\mathrm{h}} \\
\pm 0.274 \\
\end{array}$ & $\begin{array}{l}88.957^{\mathbf{h}} \\
\pm 3.472 \\
\end{array}$ \\
\hline \multicolumn{2}{|c|}{ Control $(+v e)^{1}$} & $\begin{array}{l}11.958^{\mathrm{a}} \\
\pm 0.461 \\
\end{array}$ & $\begin{array}{c}155.284^{\mathrm{a}} \\
\pm 3.700 \\
\end{array}$ \\
\hline \multicolumn{2}{|c|}{$\begin{array}{l}\text { Medium fat diet (MFD) } \\
\text { Control }(+\mathrm{ve})^{2}\end{array}$} & $\begin{array}{l}9.442^{b} \\
\pm 0.379\end{array}$ & $\begin{array}{c}139.833^{b} \\
\pm 3.188\end{array}$ \\
\hline \multirow{6}{*}{ 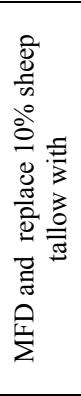 } & $10 \%$ SS oil & $\begin{array}{r}8.444^{\mathrm{c}} \\
\pm 0.379 \\
\end{array}$ & $\begin{array}{c}129.233^{\mathrm{c}} \\
\pm 2.938\end{array}$ \\
\hline & $\begin{array}{l}\text { SS, which provided the diet } \\
\text { with } 10 \% \text { oil). }\end{array}$ & $\begin{array}{c}7.182^{\mathrm{e}} \\
\pm 0.235\end{array}$ & $\begin{array}{c}116.517^{\mathrm{e}} \\
\pm 1.806\end{array}$ \\
\hline & $10 \%$ FS oil & $\begin{array}{l}7.838^{\mathrm{d}} \\
\pm 0.272\end{array}$ & $\begin{array}{c}123.126^{\mathrm{d}} \\
\pm 2.703\end{array}$ \\
\hline & $\begin{array}{l}\text { FS, which provided the diet } \\
\text { with } 10 \% \text { oil. }\end{array}$ & $\begin{array}{c}6.708^{f} \\
\pm 0.327 \\
\end{array}$ & $\begin{array}{c}110.523^{\mathrm{f}} \\
\pm 3.081 \\
\end{array}$ \\
\hline & $5 \% \mathrm{SSO}$ and $\% \mathrm{FSO}$ & $\begin{array}{l}7.204^{\mathrm{e}} \\
\pm 0.192\end{array}$ & $\begin{array}{c}116.260^{\mathrm{e}} \\
\pm 3.130\end{array}$ \\
\hline & $\begin{array}{l}\text { SS and FS, which provided } \\
\text { the diet with } 10 \% \text { oils. }\end{array}$ & $\begin{array}{l}6.192^{\mathrm{g}} \\
\pm 0.254\end{array}$ & $\begin{array}{l}100.141^{\mathrm{g}} \\
\pm 3.416\end{array}$ \\
\hline
\end{tabular}

MFD: Medium-fat diets SS: sesame seeds SSO: sesame seeds oil FS: Flax seeds FSO: Flax seeds oil Least significant differences at $\mathrm{P} \leq 0.05$.

Means with the same letter are insignificantly difference. 
The effect of medium-fat diets containing flaxseeds, sesame seeds and their oils on serum lipid profile including, cholesterol, triglycerides, high density lipoprotein cholesterol HDL-c, low density lipoprotein cholesterol LDL-c and VLDL-c (mg/dl) of non-alcoholic fatty liver disease in rats presented in Table (6).

Total cholesterol, triglycerides, LDL-c and VLDL-c increased significantly $(\mathrm{p} \leq 0.05)$, while HDL-c decreased in NAFLD rats fed on HFD (control +ve) ${ }^{1}$, as compared to normal rats (control -ve group) fed on basal diet. On the other hand, feeding NAFLD rats on MFD (control +ve $)^{2}$ led to significant decreased in all parameters, except HDL-c which showed significant increase, as compared to NAFLD rats fed on HFD.

Treating NAFLD groups with $10 \%$ (SSO, FSO and their combination) or SS, FS and their combination (which provided the diets with $10 \%$ oils) caused significant decrease $(\mathrm{p} \leq 0.05)$ in serum cholesterol, triglycerides, LDL-c and VLDL-c, while HDL-c recorded significant increase, as compared to the positive control groups. 
Samar El-Sayed Mohamed

Table (6): Effect of medium-fat diets containing flaxseeds, sesame seeds and their oils on organs and PFP of non-alcoholic fatty liver disease in rats.

\begin{tabular}{|c|c|c|c|c|c|c|}
\hline \multirow{2}{*}{\multicolumn{2}{|c|}{$\begin{array}{ll}\text { Groups } & \text { Parameters } \\
\end{array}$}} & T.Ch. & Trig. & HDL-c & LDL-c & VLDL-c \\
\hline & & & & & & \\
\hline \multicolumn{2}{|c|}{ Control (-ve) } & $\begin{array}{l}84.166^{\mathbf{g}} \\
\pm 4.241\end{array}$ & $\begin{array}{l}51.802^{\mathrm{g}} \\
\pm 2.634\end{array}$ & $\begin{array}{l}52.767^{\mathrm{a}} \\
\pm 1.901\end{array}$ & $\begin{array}{l}21.038^{h} \\
\pm 1.996\end{array}$ & $\begin{array}{l}10.360^{\mathrm{g}} \\
\pm 0.526\end{array}$ \\
\hline \multicolumn{2}{|c|}{ Control $(+v e)^{1}$} & $\begin{array}{l}175.120^{\mathrm{a}} \\
\pm 5.296\end{array}$ & $\begin{array}{l}99.370^{\mathrm{a}} \\
\pm 4.057\end{array}$ & $\begin{array}{l}24.230^{\mathrm{g}} \\
\pm 2.737\end{array}$ & $\begin{array}{l}131.02^{\mathrm{a}} \\
\pm 2.291\end{array}$ & $\begin{array}{l}19.873^{a} \\
\pm 0.811\end{array}$ \\
\hline \multicolumn{2}{|c|}{$\begin{array}{l}\text { Medium fat diet (MFD) } \\
\text { Control }(+v e)^{2}\end{array}$} & $\begin{array}{c}150.293^{b} \\
\pm 2.484\end{array}$ & $\begin{array}{l}85.615^{b} \\
\pm 4.864\end{array}$ & $\begin{array}{l}29.279^{f} \\
\pm 1.233\end{array}$ & $\begin{array}{l}103.89^{b} \\
\pm 0.753\end{array}$ & $\begin{array}{l}17.122^{b} \\
\pm 0.972\end{array}$ \\
\hline \multirow{6}{*}{ 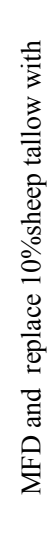 } & $10 \%$ SS oil & $\begin{array}{l}140.773^{\mathrm{c}} \\
\pm 2.190\end{array}$ & $\begin{array}{l}78.055^{\mathrm{c}} \\
\pm 1.996\end{array}$ & $\begin{array}{l}37.091^{\mathrm{e}} \\
\pm 2.193\end{array}$ & $\begin{array}{l}88.071^{\mathrm{c}} \\
\pm 1.244\end{array}$ & $\begin{array}{l}15.610^{\mathrm{c}} \\
\pm 0.399\end{array}$ \\
\hline & $\begin{array}{l}\text { SS, which provided the } \\
\text { diet with } 10 \% \text { oil). }\end{array}$ & $\begin{array}{l}132.774^{\mathrm{d}} \\
\pm 2.316\end{array}$ & $\begin{array}{l}73.733^{d} \\
\pm 2.441\end{array}$ & $\begin{array}{l}40.294^{d} \\
\pm 1.606\end{array}$ & $\begin{array}{l}77.733^{d} \\
\pm 1.752\end{array}$ & $\begin{array}{l}14.746^{\mathrm{d}} \\
\pm 0.488\end{array}$ \\
\hline & $10 \%$ FS oil & $\begin{array}{l}133.451^{\mathrm{d}} \\
\pm 2.168\end{array}$ & $\begin{array}{l}69.494^{\mathrm{e}} \\
\pm 1.535\end{array}$ & $\begin{array}{l}41.390^{\mathrm{cd}} \\
\pm 1.708\end{array}$ & $\begin{array}{l}78.163^{d} \\
\pm 1.649\end{array}$ & $\begin{array}{l}13.898^{\mathrm{e}} \\
\pm 0.306\end{array}$ \\
\hline & $\begin{array}{l}\text { FS, which provided the } \\
\text { diet with } 10 \% \text { oil. }\end{array}$ & $\begin{array}{l}124.124^{\mathrm{e}} \\
\pm 1.487\end{array}$ & $\begin{array}{l}67.665^{\mathrm{e}} \\
\pm 1.984\end{array}$ & $\begin{array}{l}42.397^{\mathrm{cd}} \\
\pm 2.084\end{array}$ & $\begin{array}{l}68.194^{\mathrm{f}} \\
\pm 1.462\end{array}$ & $\begin{array}{l}13.532^{\mathrm{e}} \\
\pm 0.396\end{array}$ \\
\hline & $5 \%$ SSO and $\%$ FSO & $\begin{array}{l}127.440^{\mathrm{e}} \\
\pm 2.535\end{array}$ & $\begin{array}{l}63.527^{\mathrm{f}} \\
\pm 0.977^{2}\end{array}$ & $\begin{array}{c}43.482^{b c} \\
\pm 1.855\end{array}$ & $\begin{array}{l}71.259^{\mathrm{e}} \\
\pm 2.380\end{array}$ & $\begin{array}{l}12.705^{f} \\
\pm 0.195\end{array}$ \\
\hline & $\begin{array}{l}\text { SS and FS, which } \\
\text { provided the diet with } \\
10 \% \text { oils. }\end{array}$ & $\begin{array}{c}115.423^{\mathrm{f}} \\
\pm 2.160\end{array}$ & $\begin{array}{l}61.410^{f} \\
\pm 2.693\end{array}$ & $\begin{array}{l}45.468^{\mathbf{b}} \\
\pm 2.206\end{array}$ & $\begin{array}{l}57.673^{\mathrm{g}} \\
\pm 1.528\end{array}$ & $\begin{array}{l}12.281^{\mathrm{f}} \\
\pm 0.538\end{array}$ \\
\hline
\end{tabular}

MFD: Medium-fat diets SS: sesame seeds SSO: sesame seeds oil

FS: Flax seeds $\quad$ FSO: Flax seeds oil

Least significant differences at $\mathrm{P} \leq 0.05$.

Means with the same letter are insignificantly difference.

The results in this Table revealed that, lipid profile in the groups which treated with FS and FSO recorded more improvement, than that of SS and SSO groups. On the other hand, the best results in lipid profile recorded for NAFLD group fed on MFD containing SS and FS provided the diet with $10 \%$ oils, followed by the group treated with $(5 \% \mathrm{SSO}$ $+5 \%$ FSO) and the group which treated with FS which provided the diet with $10 \%$, respectively. 
Peters, (2003) reported that, dietary fat is considered an important factors contributing to the obesity. Flaxseed (Linum usitatissimum L.) classified as a functional food, flaxseed leading source of the dietary fiber, phytochemical (flavonoids, lignans, phenolic acids, phytic acid, and tocopherols) and high amount of alpha-linolenic acid (Oomah and Mazza, 1998 and Oomah 2001). Lignans in the flaxseed have antioxidant activity (Xue et al, 1992) and therefore may also be of benefit in the prevention of cardiovascular disease (Hertog et al., 1993). In this respect, Park et al., (2012) suggested that lignan - enriched flaxseed supplementation may provide beneficial effects such as the reduction of body weight and fat accumulation, and improving the lipid profiles of cholesterols.

Paulina et al., (2018) also documented Consumption of flaxseeds has been shown to improve dyslipidemia and reduce blood pressure. Flaxseeds also have some antiinflammatory and anti-obesity actions. Interestingly, all the aforementioned beneficial effects of flaxseed have been attributed not only to PUFAs, mainly-linolenic acid, but also to fiber and lignans. Thakur et al., (2009) reported that, added flaxseed fiber to bread lowered the level of cholesterol in diabetics. Also, Pan et al., (2009) reported that, consumption of flaxseed decreased both total and LDL-cholesterol. On the other hand, Mandasescu et al., (2005) reported that flaxseed supplementation (as a source of linolenic acid, LNA) decreased total cholesterol by about (17.2\%), LDL-C (3.9\%), triglycerides $(36.3 \%)$ and the ratio between TC/HDL-C (33.5\%) in hyperlipidemic patients. Also Bloodon and Szapary, (2004). suggested that 
Samar El-Sayed Mohamed

flaxseed and its omega-3 fatty acid, alpha-linolenic acid (ALA) induce $11 \%$ decreases in (TC).

Bhaskaran et al., (2006) reported that, diet containing sesame oil prevented atherosclerosis in male mice. The levels of plasma cholesterol, triglyceride, low and very low density lipoprotein-cholesterol were decreased in, as compared with atherosclerotic diet-fed animals, while plasma high density lipoprotein level was significantly increased in sesame diet-fed animals. In this respect, (Satchithanandam et al., 1996) reported that, sesame oil could lower the level of lipid in serum as well as in liver of rodents.

Ashakumary et al., (1999) reported that, sesame oil also contains lignans that are known to complex cholesterol from the gut and prevent cholesterol absorption. While Akanya et al., (2015) reported that, reduction in cholesterol levels observed in diabetic groups which were treated with sesame may be due to the presence of saponins. Saponins have been reported to form complexes with cholesterol and bile acids and prevent them from being absorbed through the small intestine hence lowers the cholesterol level in the blood and liver. On the other hand, Sirato Yasumoto et al., (2001) found that, sesame seed oil has been shown to maintain good cholesterol (HDL) and lowers bad cholesterol (LDL).

The effect of medium-fat diets containing flaxseeds, sesame seeds and their oils on liver enzymes including Aspartate Amino Transferase (AST), Alanine Amino Transferase (ALT) and alkaline phosphatase (ALP) of nonalcoholic fatty liver disease in rats presented in Table (7). 
Data in this table showed that, feeding NAFLD rats on HFD increased the mean values of serum AST, ALT and ALP significantly, as compared to healthy rats fed on basal diet. While feeding NAFLD rats on MFD induced significant decrease $(p \leq 0.05)$ in all liver enzymes parameters, as compared to the rats which suffer from NAFLD and fed on HFD. Results in the present study indicated that, treating NAFLD groups with MFD containing SS, FS, combination of them and their oils improved the parameters of liver enzymes (AST, ALT and ALP), as compared to the group which treated with MFD only. The highest improvement in these parameters recorded for the group which treated with the combination of SS and FS which provided the diet with $10 \%$ oil, followed by the groups which treated with $(5 \% \mathrm{SSO}+5 \% \mathrm{FSO})$ and FS which provided the diet with $10 \%$ oil.

Consumption of high caloric diet led to lipid accumulation (Asai and Miyazawa, 2001), increased the production of inflammatory cytokines, and the progression of liver disease (Wei et al., 2007). On the other hand, (Cao et al., 2010) showed that HFD could induce hyperlipidemia in rats, and hyperlipidemia could alter the related marker enzyme profiles in serum and liver tissue and progress to liver cirrhosis 
Samar El-Sayed Mohamed

Table (7): Effect of medium-fat diets containing flaxseeds, sesame seeds and their oils on liver enzymes of non-alcoholic fatty liver

disease in rats.

\begin{tabular}{|c|c|c|c|c|}
\hline \multirow{2}{*}{\multicolumn{2}{|c|}{ Groups $\quad$ Parameters }} & AST & ALT & ALP \\
\hline & & \multicolumn{3}{|c|}{$\mathbf{U} / \mathbf{l}$} \\
\hline \multicolumn{2}{|c|}{ Control (-ve) } & $\begin{array}{l}71.502^{\mathrm{g}} \\
\pm 1.721\end{array}$ & $\begin{array}{l}22.735^{\mathrm{g}} \\
\pm 1.284\end{array}$ & $\begin{array}{l}95.368^{\mathrm{g}} \\
\pm 3.378\end{array}$ \\
\hline \multicolumn{2}{|c|}{ Control $(+v e)^{1}$} & $\begin{array}{c}126.894^{\mathrm{a}} \\
\pm 4.294\end{array}$ & $\begin{array}{l}79.394^{\mathrm{a}} \\
\pm 3.196\end{array}$ & $\begin{array}{c}268.319^{\mathrm{a}} \\
\pm 6.867\end{array}$ \\
\hline \multicolumn{2}{|c|}{$\begin{array}{l}\text { Medium fat diet (MFD) } \\
\text { Control }(+v e)^{2}\end{array}$} & $\begin{array}{l}108.768^{b} \\
\pm 4.532\end{array}$ & $\begin{array}{l}65.519^{b} \\
\pm 3.248\end{array}$ & $\begin{array}{l}249.818^{b} \\
\pm 7.178\end{array}$ \\
\hline \multirow{6}{*}{ 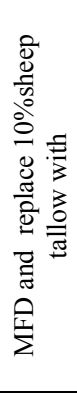 } & $10 \%$ SS oil & $\begin{array}{l}90.622^{\mathrm{c}} \\
\pm 2.225\end{array}$ & $\begin{array}{l}59.780^{\mathrm{c}} \\
\pm 2.598\end{array}$ & $\begin{array}{c}226.001^{\mathrm{c}} \\
\pm 1.611^{\mathrm{N}}\end{array}$ \\
\hline & $\begin{array}{l}\text { SS, which provided the diet } \\
\text { with } 10 \% \text { oil). }\end{array}$ & $\begin{array}{l}85.866^{\mathrm{d}} \\
\pm 2.145\end{array}$ & $\begin{array}{l}55.479^{\mathrm{d}} \\
\pm 2.978\end{array}$ & $\begin{array}{c}215.447^{\mathrm{d}} \\
\pm 3.119\end{array}$ \\
\hline & $10 \%$ FS oil & $\begin{array}{l}87.187^{\text {cd }} \\
\pm 2.161\end{array}$ & $\begin{array}{l}54.323^{\mathrm{d}} \\
\pm 2.438\end{array}$ & $\begin{array}{l}216.482^{\mathrm{d}} \\
\pm 2.502\end{array}$ \\
\hline & $\begin{array}{l}\text { FS, which provided the diet } \\
\text { with } 10 \% \text { oil. }\end{array}$ & $\begin{array}{l}81.370^{\mathrm{e}} \\
\pm 2.531\end{array}$ & $\begin{array}{l}49.627^{\mathrm{e}} \\
\pm 3.536 \\
\end{array}$ & $\begin{array}{l}204.236^{\mathrm{e}} \\
\pm 2.987\end{array}$ \\
\hline & $5 \% \mathrm{SSO}$ and $\% \mathrm{FSO}$ & $\begin{array}{l}81.742^{\mathrm{e}} \\
\pm 2.341\end{array}$ & $\begin{array}{l}49.056^{\mathrm{e}} \\
\pm 2.518\end{array}$ & $\begin{array}{l}207.313^{\mathrm{e}} \\
\pm 3.408\end{array}$ \\
\hline & $\begin{array}{l}\text { SS and FS, which provided } \\
\text { the diet with } 10 \% \text { oils. }\end{array}$ & $\begin{array}{l}77.224^{f} \\
\pm 2.413\end{array}$ & $\begin{array}{l}44.782^{f} \\
\pm 3.385\end{array}$ & $\begin{array}{l}195.491^{f} \\
\pm 3.669\end{array}$ \\
\hline
\end{tabular}

MFD: Medium-fat diets SS: sesame seeds SSO: sesame seeds oil

FS: Flax seeds

FSO: Flax seeds oil

Least significant differences at $\mathrm{P} \leq 0.05$.

Means with the same letter are insignificantly difference.

Paulina et al., (2018) reported that, bacterial glycolytic activity increased in the distal intestine by flaxseeds and led to decrease hepatic fat " especially triglyceride accumulation" Flaxseed decrease lipid peroxidation in the kidneys and increase the blood HDL cholesterol concentration. Flaxseed which have high amount of omega-3 polyunsaturated fatty acid, have significant hepatoprotective properties (Parker et al., 2012). On the other hand, Naqshbandi et al., (2012) reported that, dietary supplementation of flaxseed oil improved the effects of hepatotoxic in rats which induced by Cisplatin. Faseehuddin and Madhusudhan, (2007) reported that, 
flaxseed chutney supplemented diet could lower the serum cholesterol and as a potential source of antioxidants it could exert protection against hepatotoxic damage induced by carbon tetrachloride $\left(\mathrm{CCl}_{4}\right)$ in rats.

Sesame seed consumption appears to increase plasma gamma-tocopherol and enhanced vitamin $\mathrm{E}$ activities (Baselt, 2008) which are belived to prevent the fatty accumulation and vaculation at the cellular level (Sanyal et al., 2004). Sesame lignans have antioxidant property which can inhibit the absorption and the production of cholesterol in the liver (Kato et al., 1998). Also, the protective effect of flavonoid of sesamum seed was attributed to its antioxidant and free radical scavenging properties (Takeoka and Dao (2003). Sesamin has been known to protect the liver from oxidative damage (Sirato Yasumoto et al., 2001).

The effect of medium-fat diets containing flaxseeds, sesame seeds and their oils on antioxidant enzymes including Glutathione (GSH), superoxide dismutase (SOD) and catalase (CAT) of non-alcoholic fatty liver disease in rats presented in Table (8).

The mean values of GSH, SOD and CAT of NAFLD group which was fed on HFD (control $+\mathrm{ve})^{1}$ decreased significantly $\mathrm{p} \leq 0.05$, as compared to the negative control group. Meanwhile, feeding NAFLD group on MFD (control -ve) ${ }^{2}$ increased the antioxidant enzymes, as compared to those fed on HFD (control +ve) ${ }^{1}$.

Treating NAFLD groups with MFD containing sesame oil, flax seeds oil, combination of then and their seeds, led to significant increase in the antioxidant enzymes 
Samar El-Sayed Mohamed

(GSH, SOD and CAT), as compared to the positive control groups (control -+ve) ${ }^{1 \& 2}$.

Flaxseeds and its oil showed more effect in increasing the antioxidant enzymes, than that of sesame seeds or sesame seeds oil. On the other hand, the best results in these enzymes was recorded for the group treated with combination of sesame seeds SS and Flaxseeds FS together, which provided the diet with $10 \%$ oils, followed by the groups fed on MFD containing FS, which provided the diet with $10 \%$ oil and the combination of sesame seeds oil and flaxseeds oil, respectively.

Safer and natural antioxidants are generally required for food, biological, and pharmaceutical systems. Plant constituents with antioxidant activity and free radical scavenging effects are regarded as the safe source for these antioxidants, as it was reported that synthetic antioxidants have shown adverse effects including mutagenic, carcinogenic, and toxic effects (Kalın et al., 2015). Phenolic compounds, which can be obtained from flaxseed (Linum usitatissimum L.) oil, are the most widely occurring chemicals, having strong antioxidant properties (Gulçin et al., 2011). Phenolic compounds exhibit their antioxidant activity owing to their redox property. p-hydroxybenzoic acid, ellagic acid, p-coumaric acid, ferulic acid, and ascorbic acid are the main phenolic acids in flaxseeds (Han et al., 2018).

Rajesha et al. (2006) indicated that, beneficial flaxseed antioxidant components help to restore the elevated activity of hepatic marker enzymes like catalase, SOD and peroxide dismutase at almost normal level in weanling 
albino rats which treated with $\mathrm{CCl}$. Further, in another study it was demonstrated that dietary flaxseed supplementation increases antioxidant defenses through both reduced ROS generation and increased ROS detoxification (Lee et al., 2008).

Mohamed et al., (2013) reported that, sesame oil offered significant protection against isoproterenol induced oxidative myocardial injury through augmentation of antioxidant enzyme, results of that study shows protective mechanism via decreasing thiobarbituric acid reactive substance (TBARS) and enhancing the endogenous antioxidant enzymes (reduced glutathione (GSH), superoxide dismutase (SOD) and Catalase) in male Wistar albino rats which treated orally with $(5$ and $10 \mathrm{ml} / \mathrm{kgb} . \mathrm{w}$. for thirty days.

Table (8): Effect of medium-fat diets containing flaxseeds, sesame seeds and their oils on the antioxidant enzymes in liver tissue in non-alcoholic fatty liver disease rats.

\begin{tabular}{|c|c|c|c|c|}
\hline \multicolumn{2}{|c|}{$\mathrm{C}_{\text {Groups }}$ Parameters } & $\begin{array}{c}\text { GSH } \\
\text { mg/g Liver }\end{array}$ & $\begin{array}{c}\text { SOD } \\
\text { U/g liver }\end{array}$ & $\begin{array}{c}\text { CAT } \\
\text { mmol/g liver }\end{array}$ \\
\hline \multicolumn{2}{|c|}{ Control (-ve) } & $\begin{array}{l}0.372^{\mathrm{a}} \\
\pm 0.013 \\
\end{array}$ & $\begin{array}{l}0.351^{\mathrm{a}} \\
\pm 0.010\end{array}$ & $\begin{array}{l}0.385^{\mathrm{a}} \\
\pm 0.008\end{array}$ \\
\hline \multicolumn{2}{|c|}{ Control $(+\mathrm{ve})^{1}$} & $\begin{array}{r}0.202^{\mathrm{g}} \\
\pm 0.014\end{array}$ & $\begin{array}{r}0.251^{\mathrm{f}} \\
\pm 0.007\end{array}$ & $\begin{array}{r}0.144^{\mathrm{g}} \\
\pm 0.008\end{array}$ \\
\hline \multicolumn{2}{|c|}{$\begin{array}{l}\text { Medium fat diet (MFD) } \\
\text { Control }(+\mathrm{ve})^{2}\end{array}$} & $\begin{array}{r}0.236^{\mathrm{f}} \\
\pm 0.008 \\
\end{array}$ & $\begin{array}{l}0.276^{\mathrm{e}} \\
\pm 0.010 \\
\end{array}$ & $\begin{array}{r}0.248^{f} \\
\pm 0.006 \\
\end{array}$ \\
\hline \multirow{5}{*}{ 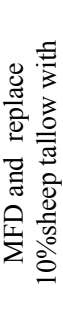 } & $10 \%$ SS oil & $\begin{array}{l}0.256^{\mathrm{e}} \\
\pm 0.012\end{array}$ & $\begin{array}{l}0.295^{\mathrm{d}} \\
\pm 0.009\end{array}$ & $\begin{array}{l}0.299^{\mathrm{e}} \\
\pm 0.008\end{array}$ \\
\hline & $\begin{array}{l}\text { SS, which provided } \\
\text { the diet with } 10 \% \text { oil). }\end{array}$ & $\begin{array}{l}0.286^{\mathrm{d}} \\
\pm 0.007 \\
\end{array}$ & $\begin{array}{r}0.319^{\mathbf{c}} \\
\pm 0.003 \\
\end{array}$ & $\begin{array}{l}0.310^{\mathrm{de}} \\
\pm 0.009 \\
\end{array}$ \\
\hline & $10 \%$ FS oil & $\begin{array}{l}0.306^{\mathbf{c}} \\
\pm 0.008\end{array}$ & $\begin{array}{l}0.320^{\mathbf{c}} \\
\pm 0.007\end{array}$ & $\begin{array}{l}0.315^{\text {cd }} \\
\pm 0.009\end{array}$ \\
\hline & $\begin{array}{l}\text { FS, which provided } \\
\text { the diet with } 10 \% \text { oil. }\end{array}$ & $\begin{array}{r}0.327^{\mathbf{b}} \\
\pm 0.006 \\
\end{array}$ & $\begin{array}{l}0.331^{\mathbf{b}} \\
\pm 0.010 \\
\end{array}$ & $\begin{array}{l}0.328^{\mathbf{b}} \\
\pm 0.009 \\
\end{array}$ \\
\hline & $5 \% \mathrm{SSO}$ and $\% \mathrm{FSO}$ & $\begin{array}{l}0.329^{\mathbf{b}} \\
\pm 0.009\end{array}$ & $\begin{array}{l}0.327^{b c} \\
\pm 0.006\end{array}$ & $\begin{array}{l}0.324^{\mathrm{bc}} \\
\pm 0.008\end{array}$ \\
\hline
\end{tabular}

Egyptian Journal for Specialized Studies - Vol (8) N (27) July 2020 
Samar El-Sayed Mohamed

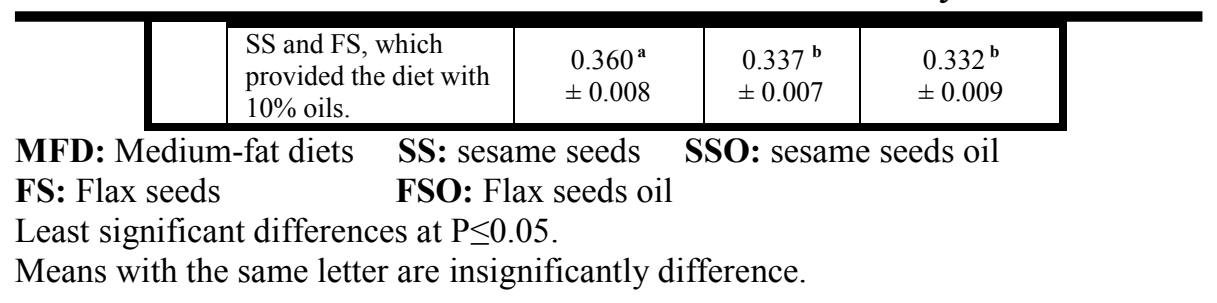

\section{REFERENCES:}

- Aebi, H.E. (1984). Catalse in vitro. Methods in Enzymology, 105:121-126.

- Akanya, H. O.; Isa, U. L.; Adeyemi1, H. R. and Ossamulu, I. F. (2015). Effect of Sesamum indicum (Linn) Seeds Supplemented Diets on Blood Glucose, Lipid Profiles and Serum Levels of Enzymes in Alloxan Induced Diabetic Rats. Journal of Applied Life Sciences International 2(3): 134-144.

- Alberti, K.G.; Zimmet, P. and Shaw, J. (2005). Epidemiology Task Force Consensus, Group. The metabolic syndrome - a new worldwide definition. Lancet; 9491: 1059-62.

- Allain, C.; Poon, L. and Chan, C. (1974): Enzymatic determination of total serum cholesterol. Clin. Chem., 20:470475.

- Anstee, Q.M. and Goldin, R.D. (2006). Mouse models in nonalcoholic fatty liver disease and steatohepatitis research. Int $\mathrm{J}$ Exp Pathol 87: 1-16.

- A.O.A.C. (2000). Official Method of the Analysis of AOAC International, 17thed volume II. Association of Official Analytical Chemists Gaithersburg,Maryland. USA.

- A.O.A.C. (1975): Official methods of analysis of association of official agricultural chemists, Washington, D.C.

- Araya, J.; Rodrigo, R.; Videla, L.A.; Thielemann, L.; Orellana, M. and Pettinelli, P. (2004). Increase in long-chain polyunsaturated fatty acid $n-6 / n-3$ ratio in relation to hepatic steatosis in patients with non-alcoholic fatty liver disease. Clin Sci; 106:635-643. 
- Asai, A. and Miyazawa, T. (2001). Dietary curcuminoids prevent high-fat diet-induced lipid accumulation in rat liver and epididymal adipose tissue. J Nutr., 131: 2932-2935

- Ashakumary, L.; Rouyer, I.; Takahashi, Y.; Ide, T.; Fukuda, N.; Aoyama, T.; Hashimoto, T.; Mizugaki, M. and Sugano, M. (1999). Sesamin, a sesame lignan, is a potent inducer of hepatic fatty acid oxidation in the rat. Metabolism;48:13031313.

- Baranowski, M.; Enns, J.; Blewett, H.; Yakandawala, U.; Zahradka, P. and Taylor, G.C. (2012): Dietary Flaxseed oil reduces adipocyte size, adipose monocyte chemoattractant protein-1 levels and T-cell infiltration in obese, insulin-resistant rats. Cytokine., 59: 382-391.

- Baselt, R. (2008). Disposition of Toxic Drugs and Chemicals in Man, 8th edition, Biomedical Publications, Foster City, CA, 1271-1272.

- Beauchamp, C. and Fridovich, I. (1971). Superoxide dismutase: Improved assays and an assay applicable to acrylamide gels. Anal. Biochem., 44: 276-287.

- Belfield, A. and Goldberg, D. M. (1971). Normal Ranges and Diagnostic Value of Serum 5'Nucleotidase and Alkaline Phosphatase Activities in Infancy. Arch Dis Child ; 46:842-846.

- Bellentani, S. and Marino, M. (2009). Epidemiology and natural history of non-alcoholic fatty liver disease (NAFLD). Ann Hepatol; 8(Suppl. 1): S4-8.

- Bhaskaran, S.; Santanam, N.; Penumetcha, M. and Parthasarathy, S. (2006). Inhibition of Atherosclerosis in LowDensity Lipoprotein Receptor-Negative Mice by Sesame Oil. J Med Food 9 (4) : 487-490

- Bloodon, L.T. and Szapary, P.O. (2004): Flaxseed and Cardiovascular risk. Nutr. Rev., 62: 18-27.

- Bluher, S. and Mantozoros, C.S. (2004): The role of leptin in regulation neuroendocrine function in humans. J. Nutr., 134 : $2469 S-2474 S$. 
Samar El-Sayed Mohamed

- Borchani C.; Besbes, S. and Attia, H. (2010). "Chemical Characteristics and Oxidative Stability of Sesame Seed, Sesame Paste and Olive Oils". Journal of Agricultural Science and Technology 12: 585-596.

- Brant, L.H.C.; Cardozo, L.F.; Velarde; L.G.C. and Boaventura, G.T. (2012). Impact of flaxseed intake upon metabolic syndrome indicators in female Wistar rats. Acta Cir. Bras. vol.27 no.8, Aug. 2012

- Brehm, B.J.; Lattin, B.L.; Summer, S.S.; Boback, J.A.; Gilchrist, G.M. and Jandacek, R.J. (2009). One-year comparison of a high-monounsaturated fat diet with a highcarbohydrate diet in type 2 diabetes. Diabetes Care.;32:215-20.

- Cao, Z.H.; Gu, D.H.; Lin, Q.Y.; Xu, Z.Q.; Huang, Q.C.; Rao, H.; Liu, E.W.; Jia, J.J. and Ge, C.R. (2010). Effect of pu-erh tea on body fat and lipid profiles in rats with dietinduced obesity. Phytother Res., 25 (2):234-238.

- Chapman, D.G.; Castilla, R. and Campbell, J.A. (1959): Evaluation of protein in food. Determination of protein and food efficiency ratio. Can. J. Biochem. andPhysil., 37: 679-686.

- Cortez-Pinto, H.; Jesus, L.; Barros, H.; Lopes, C.; Moura, M.C. and Camilo, M.E. (2006). How different is the dietary pattern in non-alcoholic steatohepatitis patients? Clin Nutr; 25:816-823.

- Daun, J.K. and DeClercq, D.R. (1994). Sixty years of Canadian flaxseed quality surveys at the Grain Research Laboratory. In 55th Proceedings of Flax Institute of United States, p. 192-200. Fargo North Dakota: Flax Institute of United States.

- Donnelly, K.L.; Smith, C.I.; Schwarzenberg, S.J.; Jessurun, J.; Boldt, M.D. and Parks, E.J. (2005). Sources of fatty acids stored in liver and secreted via lipoproteins in patients with nonalcoholic fatty liver disease. J Clin Invest.;115(5):13431351.

- Ellman, G.L. (1959). Tissue sulfhydryl groups. Archives of Biochemistry and Biophysics, 82: 70-77. 
- Faseehuddin, S.K.A. and Madhusudhan, B. (2007): Hypocholesterolemic and hepatoprotective effects of flaxseed Chutney: evidence from animal studies. Ind J Clin Biochem., 22 (1) 117-121.

- Fernandez-Riejo, S.L.; Najib, S.; Santos, A. J.; Perez, P.A. and Yanes, G. (2010): Role of leptin in the activation of immune cells Mediators Inflarum., 568-343.

- Flatt, J.P. (1995). Use and storage of carbohydrate and fat. Am J Clin Nutr; 61: 952S-959S.

- Foster, L. B. and Dumns, T. T. (1973): Determination of triglycerides. J. Clin. Chem., 19:338-353.

- FriedWald, W.T.; Leve, R.I. and Fredrickson, D.S. (1972). Estimation of the concentration of low-density lipoprotein separation by three different methods .Cli. Chem., 18: 499-502.

- Ganorkar, P. M. and Jain, R. K. (2013). Flaxseed - a nutritional punch. International Food Research Journal 20(2): 519-525.

- Guillaume, M. and Bjorntorp, P. (1996): Obesity in Children, environmental and genetic aspects. Horm. Metab. Res. 28, 573581.

Gulçin, I.; Topal, F.; Ozturk Sarikaya, S.B.; Bursal, E.; Goren, A.C. and Bilsel, M. (2011). Polyphenol contents and antioxidant properties of medlar (Mespilus germanica $\mathrm{L}$ ). Rec Nat Prod; 5:158-175

- Gunstone, D.F.; Harwood, L.J. and Padle, B.F. (1994). The lipid handbook. Second edition. Chapman \& Hall. Printed in U.S.A.

- Han, H.; Yilmaz, H. and Gulcin, I. (2018). Antioxidant activity of flaxseed (Linum usitatissimum L.) shell and analysis of its polyphenol contents by LC-MS/MS. Rec Nat Prod; 12:397-402

- Hegsted, D.M.; Mill, R.C.; Elvehjen, C.A. and Hart E.B. (1941): Salt mixture. Journal Biological Chemical, 138-459.

- Henness, S. and Perry, C.M. (2006): Orlistat: a review of its use in the management of hobesity. Drugs, 66:1625-1656. 
- Hertog, M.G.; Feskens, E.J.; Hollman, P.C.; Katan, M.B. and Kromhout, D. (1993): Dietary antioxidant flavonoids and risk of coronary heart disease: the Zutphen Elderly Study. Lancet., 342(8878):1007-11.

- Hussein, J.; Abo Elmatty, D.; Medhat, D.; Mesbah, N.; Farrag, A.R. and Fahmy, H. (2016). Flaxseed oil attenuates experimental liver hepatitis. Der Pharmacia Lettre, 8 (8):142150.

- Kabisch, S.; Bäther, S.; Dambeck, U.; Kemper, M.; Gerbracht, C.; Honsek, C.; Sachno, A. and Pfeiffer, A. (2018). Liver Fat Scores Moderately Reflect Interventional Changes in Liver Fat Content by a Low-Fat Diet but Not by a Low-Carb Diet. Nutrients, 10, 157: 1-8.

- Kalın, P.; Gulcin, I. and Goren, A.C. (2015). Antioxidant activity and polyphenol content of Vaccinium macrocarpon. Rec Nat Prod; 9:496-502

- Kaneko, K.; Yamasaki, K.; Tokunaga, Y.; Tobsia, M. and Furuse, M. (2002). Effects of dietary sesame meal on growth, meat ingredient and lipid accumulation in broilers. Jpn. Poult. Sci., , 39: J56-J62.

- Katare, C.; Saxena, S.; Agrawal, S.; Prasad, G. and Bisen, P. (2012). Flax seed: a potential medicinal food. J. Nutr. Food Sci. 2:2.

- Kato, M.J.; Chu, A.; Davin, L.B. and Lewis, N.G. (1998). Biosynthesis of antioxidant lignans in Sesamum indicum seeds. Phytochemistry. 47: 583-591.

- Kien, C.L. (2009). Dietary interventions for metabolic syndrome: role of modifying dietary fats. Curr Diab Rep.; 9(1):43-50.

- Kratz, M.; Von Eckardstein, A.; Fobker. M.; Buyken, A. and Schulte, H. (2002): The impact of dietary fat composition on serum leptin concentration in healthy non-obese men and women. J. Clin. Endocrinol. Metab., 87 (11): 5008-14.

- Kristensen, M.; Jensen, G.M.; Aarestrup, G.M.; Aarestrup, J. and Astrup, A. (2011): Flaxseed dietary fibers lower 
cholesterol and increase fecal fat excretion. Nutr. and Metabolism., 8-9 : 1743-7075.

- Lairon, D.; Play, B. and Jourdheuil-Rahmani, D. (2007): Digestible and indigestible carbohydrates: interactions with postprandial lipid metabolism. J. Nutr. Biochem., 18:217-227.

- Lee, J. C.; Bhora, F.; Sun, J.; Cheng, G.; Arguiri, E.; Solomides, C. C.; Chatterjee, S. and Christofidousolomidou, M. (2008). Dietary flaxseed enhances antioxidant defenses and is protective in a mouse model of lung ischemia-reperfusion injury. American Journal of Physiology- Lung Cellular and Molecular Physiology 294: L255-L265.

- Lopes-Virella, M.F.; Stone, S.; Ellis, S. and Collwellm, J.A. (1977): Cholesterol determination in high-density lipoproteins separated by three different methods. Clin. Chem., 23 (5): 882893.

- Mandasescu, S.; Mocain, V.; Dascalita, A.M.; Haliga, R.; Nestian, I.; Still, P.A. and Luca, V. (2005): Flaxseed supplementation in hyperlipidemic patients. Rev. Med. Chir. Soc. Med. Nat. Tasi., 109 (3):502-6.

- Martinchik, A. N.; Baturin, A. K.; Zubtsov, V. V. and Molofeev, V. (2012). [Nutritional value and functional properties of flaxseed]. Vopr. Pitan. 81:4-10.

- Mohamed, T.S. Saleem; Madhusudhana, C. Chetty and Kavimani, S. (2013). Putative antioxidant property of sesame oil in an oxidative stress model of myocardial injury. Journal of Cardiovascular Disease Research, 4: 177- 181.

- Moraes, J.C.; Coope, A.; Morari, J.; Cintra, D.E.; Roman, E.A. and Pauli, J.R. (2009). High-fat diet induces apoptosis of hypothalamic neurons. PLoS One; 4: e5045

- Morris, D.H. (2003). Flax: A health and nutrition primer. $3^{\text {rd }}$ ed, p.11 Winnipeg: Flax Council of Canada. Downloaded from http://www.jitinc.com/flax/brochure02.pdf verified on 4/6/12.

- Naqshbandi, A.; Khan, W.; Rizwan, S. and Khan, F. (2012). Studies on the protective effect of flaxseed oil on cisplatininduced hepatotoxicity. Hum Exp Toxicol. doi:10.1177. 
- Naran, R.; Chen, G. and Carpita, N.C. (2008): Novel Rhamnogalacturonan I and Arabinoxylan Polysaccharides of Flax Seed Mucilage. Plant Physiol., 148:132-141.

- Nzikou, J.M.; Matos, L.; Bouanga-Kalou, G.; Ndangui, C.B.; Pambou-Tobi, N.P.G.; Kimbonguila, A.; Silou, Th.; Linder, M. and Desobry, S. (2009) : Chemical Composition on the Seeds and Oil of Sesame (Sesamum indicum L.) Grown in Congo-Brazzaville, Advance Journal of Food Science and Technology 1(1): 6-11.

- Oomah, B.D. (2001): Flaxseed as a functional food source. $J$. Sci. Food. Agric.; 81:889-94.

- Oomah, B. D. and Mazza, G. (1998): Flaxseed products for disease prevention, in Functional Foods Biochemical and Processing Aspects. Ed by Mazza, G., Technomic Publishing, Lancaster, PA, pp 91-138.

- Ornish, D.; Brown, S.E.; Scherwitz, L.W.; Billings, J.H.; Armstrong, W.T.; Ports, T.A. (1990). Lifestyle changes and heart disease. Lancet; 336(8717): 741-2.

- Pan, A.; Yu, D.; mark-Wahnefried, W.; Franco, O.H. and Lin, X. (2009): Meta-analysis of the effects of flaxseed interventions on blood lipids. Am. J. Clin. Nutr., 90:288-297.

- Park, B.J. and Velasquez, T.M. (2012): Potential effects of lignan - enriched flaxseed powder on body weight visceral fat, lipid profile, and blood pressure in rats. Fitoterapia; 83: 941946.

- Parker, H.M.; Johnson, N. A.; Burdon, C. A.; Cohn, J. S.; O'Connor, H. T. and George, J. (2012). Omega-3 supplementation and non-alcoholic fatty liver disease: a systematic review and metaanalysis. J. Hepatol. 56:944-951.

- Paulina M. Opyd; Adam Jurgo nski; Jerzy Ju skiewicz D.; Bartosz Fotschki D. and Jarosław Koza (2018): Comparative Effects of Native and Defatted Flaxseeds on Intestinal Enzyme Activity and Lipid Metabolism in Rats Fed a High-Fat Diet Containing Cholic Acid, Nutrients, MDPI, 10: 1181 .

- Peters, J. C. (2003). Dietary fat and body weight control. Lipids, 38:123-127. 
- Pomplun, D.; Voigt, A.; Schulz, T.J.; Thierbach, R.; Pfeiffer, A.F. and Ristow, M. (2007). Reduced expression of mitochondrial frataxin in mice exacerbates diet-induced obesity. Proc Natl Acad Sci U S A; 104: 6377-6381.

- Prentice, A.M. (1998). Manipulation of dietary fat and energy density and subsequent effects on substrate flux and food intake. Am J Clin Nutr; 67: 535S-541S.

- Raeisi-Dehkordi, H.; Mohammadi, M.; Moghtaderi, F. and Salehi-Abargouei, A. (2018). Do sesame seed and its products affect body weight and composition? A systematic review and meta-analysis of controlled clinical trials. Journal of Functional Foods 49: 324-332.

- Rajesha, J.; Murthy, C. K. N.; Kumar, M. K.; Madhusudhan, B. and Ravishankar, G. (2006). Antioxidant potentials of flaxseed by in vivo model. Journal of Agricultural and Food Chemistry 54: 3794-3799.

- Ramesh, B.; Saravanan, R. and Pugalendi, K.V. (2005). Influence of sesame oil on blood glucose, lipid peroxidation, and antioxidant status in streptozotocin diabetic rats. J Med Food.;8:377-81.

- Reeves, P.G.; Nielsen, F.H. and Fahmy, G.C. (1993): Reported of the American Institute of Nutrition adhocwriling committee on the reformulation of the AIN-76 a Rodent diet. Journal Nutrition, 123: 1939-51.

- Reitman, S. and Frankel, S. (1957): Determination of glutamate pyruvate transferase. Am. J. Clin. Path., 28:56.

- Samuel, V.T.; Liu, Z.X.; Qu, X.; Elder, B.D.; Bilz, S.; Befroy, D.; Romanelli, A.J. and Shulman, G.I. (2004). Mechanism of hepatic insulin resistance in non-alcoholic fatty liver disease. J Biol Chem 279: 32345-32353.

- Sankar, D.; Ramakrishna Rao, M.; Sambandam, G. and Pugalendi, K.V. (2006): A pilot study of open label sesame oil in hypertensive diabetes. Journal of Medicinal Food., 9 (3): 408-412. 
Samar El-Sayed Mohamed

- Sanyal, A.J.; Mofrad, P.S.; Contos, M.J.; Sargeant, C.; Luketic, V.A.; Sterling, R.K.; Stravitz, R.T.; Shiffman, M.L.; Clore, J. and Mills, A.S. (2004). A pilot study of vitamin $\mathrm{E}$ versus vitamin $\mathrm{E}$ and pioglitazone for the treatment of nonalcoholic steatohepatitis. Clin Gastroenterol Hepato., 2(12): 1107-1115

- Satchithanandam, S.; Chanderbhan, R.; Kharroubi, A.T.; Calvert, R.J.; Klurfeld, D.; Tepper, S.A. and Kritchevsky, D. (1996). Effect of sesame oil on serum and liver lipid profiles in the rat. Int J Vitam Nutr Res;66:386-392.

- Schumann, B.E.; Squires, E.J.; Leeson, S. and Hunter, B. (2003): Effect of hens fed dietary flaxseed with and without a fatty liver suplement on hepatic, plasma and production characteristics relevant to fatty liver haemorrhagic syndrome in laying hens. Br Poult Sci., 44(2):234-44.

- Seidell, J.C. (1998). Dietary fat and obesity: an epidemiologic perspective. American Journal of Clinical Nutrition; 67(Suppl. 3): $546 \mathrm{~S}-50 \mathrm{~S}$.

- Sendecor, G. and Cochran, W. (1979): Statistical methods. 6 Th, ED. Lowa state collage. U.S.A.: 871.

- Silva, F.; O'Callaghan, Y.; O'Brien, N. and Netto, F. (2013). Antioxidant capacity of flaxseed products: the effect of in vitro digestion. Plant Foods Hum. Nutr. 68:24-30.

- Singh, K. K.; Mridula, D.; Rehal, J. and Barnwal, P. (2011). Flaxseed: a potential source of food, feed and fiber. Crit. Rev. Food Sci. Nutr. 51:210-222.

- Sirato Yasumoto, S.; Katsuta, M.; Okuyama, Y.; Takahashi, Y. and Ide, T. (2001). Effect of sesame seeds rich in sesamin and sesamolin on fatty acid oxidation in rat liver. J. Agri. Food Chem.;49:2647-2651.

- Takeoka, G.R. and Dao, L.T. (2003). Antioxidantconstituent of almond (Prunus dulicis (mill) D.A. Webb huls). Journal of Agricultural and Food Chemistry., 51: 496-501.

- Tanaka, N.; Sano, K.; Horiuchi, A.; Tanaka, E.; Kiyosawa, K. and Aoyama, T. (2008). Highly purified eicosapentaenoic 
acid treatment improves nonalcoholic steatohepatitis. J Clin Gastroenterol.;42(4):413-418.

- Thakur, G.; Mitra, A.; Pal, K. and Rousseau, D. (2009): Effect of flaxseed gum on reduction of blood glucose and cholesterol in type 2 diabetic patients. Int. J. Food Sci. Nutr., 60:126-136.

- Tharwat, S.; Abd El-Megeid, A.; Salam, R.; Rashed, L.; ElHamid,S.; Abdel-Shafy, S. and Shaheen,D. (2017). Effectiveness of Adding Flaxseed to Type 2 Diabetic Patient's Regimen. Endocrinol Metab Syndr, 6 (3): 2-5.

- Trinder, P. (1959). Determination of blood glucose using 4aminophenazone. J. Clin. Path., 22:246.

- Wajchenberg, B.L. (2000). Subcutaneous and visceral adipose tissue: their relation to the metabolic syndrome. Endocr Rev; 21: 697-738.

- Wang, D.Q; Liu, X: L.; Rong. Q, F. Han, L. and Zhao, (2013): N.Q Alpha-Linolenic acid improves insulin sensitivity in obese patients. Zhonghua Yixueza Zhi, 8; 93 (2): 132-4.

- Wei, Y.; Wang, D.; Topczewski, F. and Pagliassotti, M.J. (2007). Fructose-mediated stress signaling in the liver: implication for hepatic insulin resistance. J. Nutr. Biochem., 18: $1-9$.

- Westerterp, K.R.; Smeets, A.; Lejeune, M.P.; WoutersAdriaens, M.P.; Westerterp-Plantenga, M.S. (2008). Dietary fat oxidation as a function of body fat. Am J Clin Nutr; 87: 132135.

- Xue, J.Y.; Liu, G.T.; Wei, H.L. and Pan, Y. (1992): Antioxidant activity of two dibenzocyclooctene lignans on the aged and ischemic brain in rats. Free Radic. Biol. Med., 12(2):127-35.

- Yeshajahu, Y.P. (1994). Food analysis theory and practices. Third edition. Chapman \& Hall. Printed in Great Britain.

- Younossi, Z.M.; Koenig, A.B.; Abdelatif, D.; Fazel, Y.; Henry, L.; and Wymer, M. (2016). Global Epidemiology of 
Samar El-Sayed Mohamed

Nonalcoholic Fatty Liver Disease-Meta-Analytic Assessment of Prevalence, Incidence, and Outcomes. Hepatology, 64, 73-84.

- Zarghani, S.S.; Soraya, H.; Zarei, L. and Alizadeh, M. (2016). Comparison of Three Different Diet-Induced Non Alcoholic Fatty Liver Disease Protocols in Rats: A Pilot Study. Pharmaceutical Sciences, 22, 9-15. 